\title{
TECHNOLOGY MANAGEMENT IN THE DEREGULATED ELECTRICITY DISTRIBUTION INDUSTRY: THE SOUTH AFRICAN CASE
}

\author{
M.G.B. Madonsela ${ }^{1}$ and M.O. Kachieng' ${ }^{2}$ \\ ${ }^{2}$ Department of Engineering and Technology Management \\ University of Pretoria, South Africa \\ mkachienga@eng.up.ac.za
}

\begin{abstract}
The subject of deregulation of electricity utilities has, in the past two decades, dominated the discussions on global Electricity Supply Industries (ESIs). Deregulation may be viewed as the withdrawal of state regulatory powers from the generation, transmission and distribution of electrical power to facilitate liberalised power markets. The key drivers for deregulation in South Africa are global competitiveness; a quest for local industrial development through cost-effective services; equitable and sustainable power supplies and the social empowerment of communities through the eradication of poverty. The present Electricity Distribution Industry (EDI), which is a component of the ESI, is made up of Eskom Distribution and about 368 municipal distributors. At present, both these entities run their businesses according to differing "business" principles. With technology being one of the driving forces of economic growth, this article analyses the deregulated EDI and proposes a technology management model that can be adopted after deregulation.
\end{abstract}

\section{OPSOMMING}

Gedurende die afgelope twee dekades oorheers die deregulering van elektrisiteitsvoorsiening besprekings oor die globale voorsiening van elektrisiteit. Deregulering beteken die verwydering van staatsbeheer oor die opwekking, transmissie en verspreiding van elektrisiteit om sodoende geliberaliseerde drywingsmarkte te ondersteun. Die aansporing vir deregulering in Suid-Afrika gaan om globale mededingendheid, om ondersteuning vir die ontwikkeling van plaaslike industrieë deur koste-effektiewe dienslewering, en om die voorsiening van gangbare en volhoubare kragbronne vir die bemagtiging van gemeenskappe vir die bekamping van armoede. Tans bestaan die elektriesiteitsverspreidingsbedryf uit Eskom-verspreiding en ongeveer 368 munisipale verspreiders. Hierdie samestelling maak onderling gebruik van uiteenlopende sakebeginsels. Hierdie artikel hou 'n tegnologiese bestuursmodel voor vir 'n gedereguleerde elektrisiteitsverspreidingstelsel.

\footnotetext{
${ }^{1}$ This author was enrolled for the M Eng (Engineering Management) atthe Department of Engineering and Technology Management, University of Pretoria
} 


\section{INTRODUCTION}

Before the 1970s, almost all electricity utilities world-wide were vertically integrated monopolies. That is, they controlled the generation of electricity, its transmission over long distances and its distribution to the end-user, with government as the main shareholder. The viability of this approach has always been a point of debate. In the past twenty years, a trend has developed whereby the governance of these utilities is changing. These changes include inter alia the removal of several laws that restricted competition and or the relinquishing of ownership by the public sector into the hands of the private sector (privatisation). In 1999, the South African government decided to restructure the Electricity Supply Industry (ESI).

The objectives as outlined in the government policy document can be summarised as follows [1]:

Increase access to affordable energy,

- Improve energy governance,

a Stimulate economic development,

a Manage energy-related environmental impact and secure supply through diversity,

The South African ESI is made up of Eskom (vertically integrated generation, transmission and distribution businesses) and about 368 municipal distributors. Eskom's nominal capacity is just over 41 gigawatts and accounts for approximately $95 \%$ of the country's electricity supplies. The remaining $5 \%$ is provided by these municipal distributors thataccount for $41 \%$ of Eskom Distribution's annual sales. The municipal distributors' main function is to distribute electricity on behalf of the local governments mainly to residential customers. It is for this reason that the local authorities have become known as (electricity) redistributors, as they purchase most of their electricity from Eskom Distribution to resell to the end-user.

From a power distribution viewpoint, this means that in any given magisterial district, there are at most two distributors of electricity, Eskom Distribution and or a municipal distributor. The decision by government to restructure the ESI incorporates, very roughly, the following ideas [1]:

a The generation business will be divided into 5 to 10 clusters with each cluster consisting of two to four power stations. These clusters will compete with one another with the possibility of, at a later stage, selling some of them to the private sector, thus stimulating even greater competition.

a The transmission business is likely to remain in full governmental control and ownership, providing the infrastructure for free trade.

a The EDI calls for the amalgamation of the Eskom Distribution business with the municipal distributors in order to form six independent regional electricity distributors, also known as REDs. 
One of the challenges that the EDI restructuring will pose, in the new dispensation, is the management of technology. Two previously separate business entities will be amalgamated for two reasons, namely sustainable and competitive industrial development coupled with social upliftment.

The following are some of the technology management questions that must be addressed:

- Should the suppliers of products and services drive technology advancement in the deregulated EDI, as is happening today?

- If technology would be "acquired" as it is today, how could the transfer of technology be improved throughout a given RED or the industry?

a In view of the classification of technologies in the industry, should the management of technology be carried out by a centralised body - as is done in the present Eskom Distribution or should it be decentralised so that each regional electricity distributor (RED) makes its own decisions?

- What is the best technology strategy in the deregulated electricity distribution market?

\section{TECHNOLOGIES AND THEIR CLASSIFICATION IN ELECTRICITY DISTRIBUTION INDUSTRIES}

Burgelman (1995) defines technology as the theoretical and practical knowledge, skills and artefacts that can be used to develop products and services, as well as their production delivery systems. Technology can be embodied in people, materials, cognitive and physical processes, plant, equipment and tools [2].

Ford (1996) summarises the activities of technology management as the development of longterm strategy for technology, the co-ordination of the different means of acquisition and exploitation of technology and, most important, the effective transfer of technologies between the different operating units within an organisation [3].

Technology can be developed internally or acquired externally. One form of acquiring technology is by purchasing high-tech products and services. Technology exploitation is about the utilisation of the acquired technology, whilst technology transfer is concerned with the ability of an organisation to (optimally) use and diffuse, throughout the organisation, the know-how of a given technology.

Electrical power distribution industries are made up of primary and secondary plants. The primary plant is the energy (power) delivery plant whilst the secondary plant is the one needed to ensure that energy delivery is safe, measurable, operable, sustainable and of the right quality.

Primary plant comprises overhead lines, high-and medium-voltage substations, reticulation and electrification infrastructures, whilst secondary plant comprises distribution protection and relay systems, telecommunication, telecontrol and metering. 


\begin{tabular}{|ll|cl|}
\hline \multicolumn{1}{|c|}{ Primary Plant Technologies } & \multicolumn{1}{c|}{ Secondary Plant Technologies } \\
\hline$\square$ & $\begin{array}{l}\text { Technological change is fairly static for } \\
\text { a given period }\end{array}$ & $\square$ & Technological changes are fairly rapid \\
\hline$\square$ & They are relatively expensive & $\square$ & $\begin{array}{l}\text { They are less costly when compared to } \\
\text { their primary counterparts }\end{array}$ \\
\hline$\square$ & $\begin{array}{l}\text { Their failure is catastrophic to the } \\
\text { distribution network }\end{array}$ & $\begin{array}{l}\text { Failure is not as catastrophic and can be } \\
\text { confined to smaller areas }\end{array}$ \\
\hline
\end{tabular}

\section{Table 1: The characteristics and the classification of electrical distribution technologies}

In most power utilities, both primary and secondary technologies are "acquired" from the suppliers of the products and services. Research and development (R\&D) expenditures are geared for long-term development, while the changes in primary plant technologies are slow and rarely radical. At these utilities, the management of technology tends to be centrally driven with standardisation and economies of scale as the key drivers. The pace is set at industry level, with individual firms following.

Literature and global trends show that, with the breaking down of usually larger organisations into smaller ones as part of the deregulation exercise, there is a tendency to shift management from a centralised to a decentralised form, thus providing some autonomy to the individual firms. The management of technology is no exception. A centralised approach implies that a central body throughout the industry performs the technology management function, whereas a decentralised approach implies localised decision making - some degree of autonomy. Before any approach can be loosely chosen, the market and the type of technology (primary or secondary) must be analysed.

\section{THE PRESENT SOUTH AFRICAN EDI AND THE MANAGEMENT OF TECHNOLOGY}

Eskom Distribution is divided into seven engineering regions. Technology management throughout the group is the responsibility of a centralised group known as the Distribution Technology (DT) Group. The main drivers are standardisation and the optimum utilisation of technological resources, as well as the eradication of technological duplication among the regions. Briefly stated, the management of technology within Eskom Distribution is centralised with both primary and secondary technologies mainly "acquired" from suppliers of products and services. There is, however, a limited degree of internal R\&D specifically geared to addressing specific technical problems.

Technology management at the 368 municipal distributors has always been decentralised. Each municipal distributor is autonomous, irrespective of proximity to or location in respect of the adjacent one. There was never any incentive for the municipal distributors to co-operate in the way in which they managed their technologies and consequently, every municipal distributor was autonomous. At the various municipal distributors, both primary and secondary technologies are "acquired" from the suppliers of products on a turnkey project basis. This implies that most of the capital projects (construction and sometimes maintenance) are undertaken by the suppliers of products. It is, however, fair to say that the non-uniformity 
and differing budget sizes among municipalities have made it impossible for them to cooperate, especially at operational level.

The fact that in both cases, technology is "acquired" from the suppliers of products confirms, according to De Wet (1988), that South Africa is a technology colony, i.e. it imports already commercialised artefacts [4]. The following are some of the flaws with the current situation:

- It is the suppliers of products and services that drive technology advancement on the power networks,

- The transfer of technology/expertise throughout the operating units is not spontaneous,

a There is no established relationship between the classes of technologies (primary and secondary) and the approach of technology management decision making (centralised and decentralised).

\section{A HISTORICAL OVERVIEW OF DEREGULATION OF THE GLOBAL ELECTRICITY SECTOR}

Deregulation of the electricity supply industry (ESI) is not a new phenomenon in the global arena, but in South Africa, it is. It began in the United States, following from the Public Utilities Regulatory Policy Act of 1978 that saw a partial opening of the electricity generation business. Next on the list were Chile in 1986 and England in 1990. Was it privatisation, deregulation or restructuring [5]?

McGregor (1992) defines deregulation as the process of removing the laws that restrict free trade [6]. He further defines privatisation as the process by which the State relinquishes control of certain operations into the hands of the private sector, e.g. selling State Owned Assets (SOE). What is really happening, however is more than that, it is the reorganisation of the industry, breaking up existing entities, rewriting the rules of regulation, bringing in new owners, selling assets and encouraging private firms to supply services to state-owned assets.

Restructuring is a more descriptive term of what has been happening in the industry world wide. Briefly stated, restructuring does not require a change of ownership. However, a change of ownership has not been achieved without some degree of restructuring [7].

Figure 1 shows the progress made in the global deregulation process to date. It is evident, from this barometer that some countries are more advanced than others.

Even though this article is about the electricity distribution industry, it is imperative to discuss the EDI in relation to the ESI, as that will make the picture clearer. According to Yajima (1995), a change of industry structure and a change of the energy-trading model, also known as the reform model are the two determinants that validate or define restructuring in any given ESI [5]. Using these two determinants to define the proposed business environment, one can then "decide" on the model by which technology can be managed. 


\section{Degree of Deregulation and Privatization in the Electricity Industry}

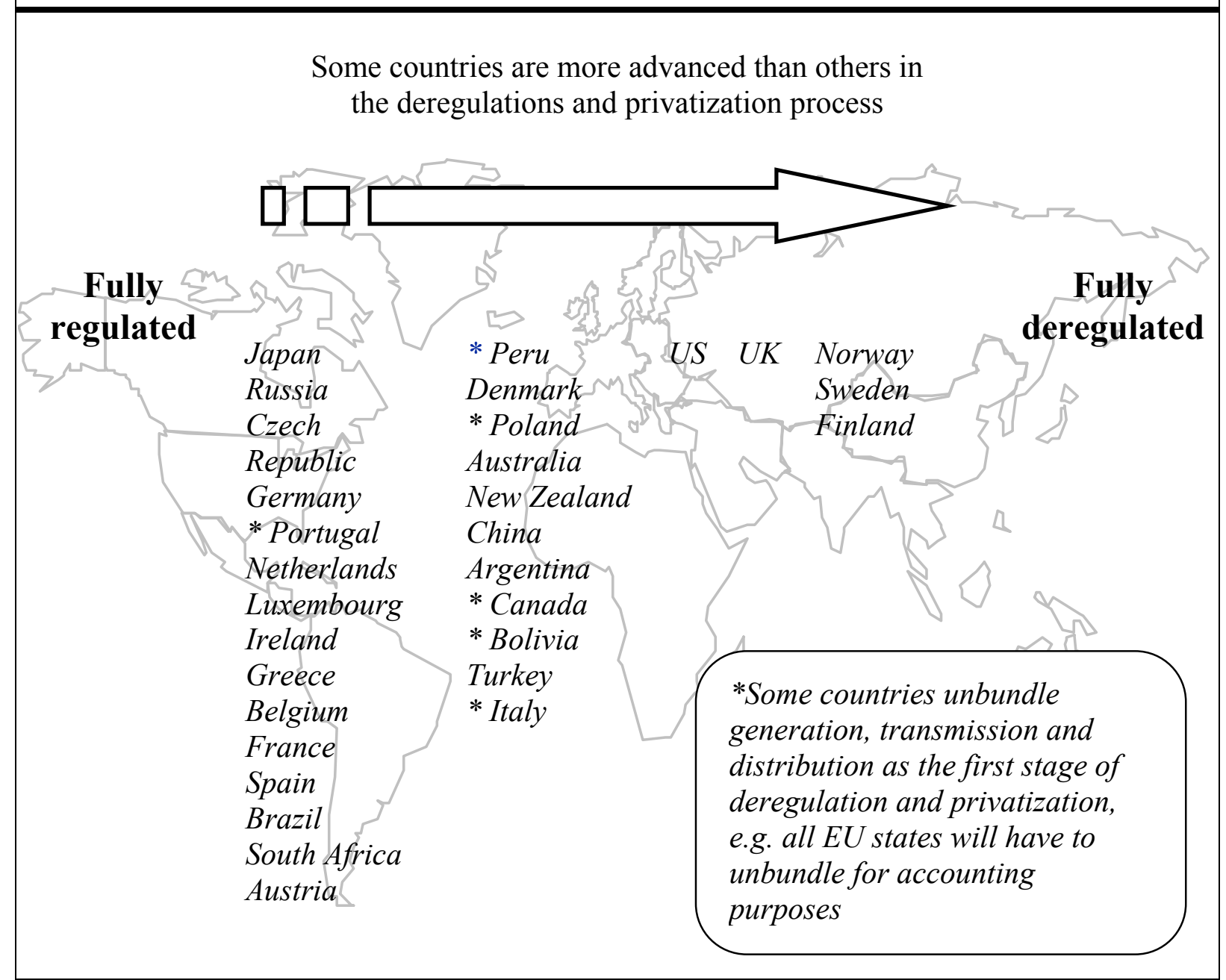

Figure 1: The global deregulation barometer

Industry structures In the context of electricity supply industries, industry structure refers to the relationship or integration of the generation $(\mathrm{G})$, transmission (T) and distribution (D) businesses with respect to energy and financial flows. There are seven industry structures according to which national ESIs can be classified [5].

At present, the South African ESI exhibits the characteristics of a combination of types 1 and 2 industry structures. According to the blueprint already approved by government, South Africa will have one national transmission utility with several generators (clusters) and six independent distributors (REDs). This will make it a type 5 industry structure.

How will the likelihood of competition being introduced change the present approaches of technology management? In order to answer the question, it is imperative to consider the second determinant for deregulation, namely the reform model.

Reform models Reform model refers to the relationship between the customers and the 
industry with respect to energy and financial flows. Maphaka \& Mpye (2001) identified four reform models [7].

\begin{tabular}{|c|l|}
\hline Type & \multicolumn{1}{|c|}{ Description } \\
\hline 1 & One fully integrated national utility. [1 GTD] \\
\hline 2 & $\begin{array}{l}\text { One integrated national generation-transmission utility and several regional } \\
\text { distributors. [ } 1 \text { GT (D) }+\mathrm{xD}]\end{array}$ \\
\hline 3 & $\begin{array}{l}\text { One utility as national transmission owner integrated in both generation and } \\
\text { distribution and several generators and regional distributors. [1 GTD +xG }+\mathrm{yD}]\end{array}$ \\
\hline 4 & $\begin{array}{l}\text { One integrated national transmission-distribution utility and several generators. [xG } \\
+1 \text { (G) TD] }\end{array}$ \\
\hline 5 & $\begin{array}{l}\text { One national transmission utility and several generators and distributors. [xG (D) }+ \\
1 \mathrm{~T}+\mathrm{y}(\mathrm{G}) \mathrm{D}]\end{array}$ \\
\hline 6 & $\begin{array}{l}\text { Several regionally integrated generation-transmission utilities and several } \\
\text { distributors. [xGT (D) + y (G)D] }\end{array}$ \\
\hline 7 & Several regional fully integrated utilities. [xGTD] \\
\hline
\end{tabular}

[Legend: $G=$ generation, $T=$ transmission, $D=$ distribution, $x, y=1,2,3 \ldots$ ]

Table 2: Industry structure types in global Electricity Supply industries

\begin{tabular}{|l|l|}
\hline \multicolumn{1}{|c|}{ Model } & \multicolumn{1}{c|}{ Description } \\
\hline 1. Monopoly & $\begin{array}{l}\text { The vertically integrated (type 1) company handles the generation, } \\
\text { transmission and distribution of electricity. There is no competition } \\
\text { at all levels. This is a pure monopoly. }\end{array}$ \\
\hline 2. Single buyer & $\begin{array}{l}\text { The purchasing agent has a choice among many generators, also } \\
\text { known as Independent Power Producers (IPPs), and has a monopoly } \\
\text { of the transmission network. This is competition from the customer } \\
\text { (single buyer) point of view. }\end{array}$ \\
\hline $\begin{array}{l}\text { 3. Wholesale } \\
\text { competition }\end{array}$ & $\begin{array}{l}\text { The distribution companies purchase direct from generators, whilst } \\
\text { they have a monopoly of customers, i.e. customers do not have a } \\
\text { choice of a distributor. Generators compete but customers are } \\
\text { monopolised. This is a monopoly from the end-user (customer) point } \\
\text { of view }\end{array}$ \\
\hline 4. Retail competition & $\begin{array}{l}\text { Open competition scenario. Customers choose their suppliers } \\
\text { (generators) with open access to the transmission and distribution } \\
\text { infrastructure. This is full competition from the end-user's point of } \\
\text { view }\end{array}$ \\
\hline
\end{tabular}

Table 3: Reform models in the global electricity supply industry

Models 3 and 4 are the only two that are applicable to the distribution business. At present, the South African ESI is a monopoly and a combination of a type 1 and 2 industry structure. The following observations are important: 
- Model 3 is also a monopoly from the EDI viewpoint, hence there is no competition in the industry - a modified monopoly.

- Model 4 describes an open competitive market. In countries such as the United Kingdom, some groups of customers have a choice among their suppliers, irrespective of their location. For the purposes of this article, Model 4 - retail competition - is regarded as full competition-full deregulation - full privatisation.

Global trends have shown that the industry structure will always follow the desired reform model, which is determined by the original drivers for deregulation [7]. Considering the twosided approach of the South African government towards restructuring, the EDI should not move directly to a retail competition scenario but should begin with the wholesale competition model. Perhaps a phased approach could be adopted where the migration to model 4 - full competition - could be introduced ten years later. During the first phase, (phase 1), a centralised approach to technology management in the industry should be adopted.

\section{THE DEREGULATED ERA AND THE TECHNOLOGY MANAGEMENT CHALLENGES}

As with all business re-engineering exercises, the benefits of this restructuring will not come without some challenges in the short, medium and long terms. Some of these challenges that will have a direct impact on the management of technology can be summarised as follows:

Customers A new generation of customers with unique requirements is slowly emerging. There is growing need to reduce the traditional arms-length distance between the customer and the supplier. In the restructured era, the customer will no longer be an ordinary customer but a role-player.

The new rules of the game The key identifier is independent. The restructured EDI calls for a streamlined industry that will be run strictly on business principles whereby the success of every RED will be determined by its bottom-line. In the end, each RED will have to justify its existence without relying on government as the only support.

Rate of change of technology In this new dispensation, the average life cycle of technologies is becoming shorter. This change calls for new methods of product evaluation, conducting feasibility studies, product development processes, manufacturing practices, marketing and after sales support. The contract periods for the supply of products or product licences have to be reassessed to ensure that the company does not become unnecessarily locked in a contract or license for unreasonable periods. This is specifically true for the secondary plant technologies in the electrical power sector.

Integration of technologies The past five years have seen an increase in the integration of both secondary and primary plant technologies. The boundaries between these are gradually fading away. Both the engineers and the technology managers require a combination of new skills. From the point of view of managing the life cycle of products, integration will always pose the compatibility problem. The common questions asked are whether the latest software is compatible with the earlier version, whether this new device will communicate with the 
older ones, whether the old channel will cope with the new speed requirements of the new device, etc. These questions must always be in the mind of the future technology manager.

Automation and customer requirements Automation has made the customer requirements such as power quality very hard to meet. The degree of reliance on technology has also increased whilst it is still obvious that technological systems are not without fault. Error free and self-diagnostic repair systems need to be developed. These unique requirements pose new challenges to the technology manager.

Cost-effectiveness of technologies Generally, the cost of secondary plant technologies has been on a downward trend while primary technologies have not shown any such move. Technology development of the latter has been extremely slow and costly.

Incentive schemes for personnel Change is not a desirable phenomenon in people's lives. Where people are involved in these changes, longer contract periods and new incentive schemes must be designed to keep them motivated and loyal.

Du Plessis (1998) concludes by saying that successful management of technology requires the following [8]:

- The capacity to orchestrate and integrate functional and specialist groups for the implementation of innovations,

- Continuous questioning of the appropriateness of technological opportunities,

- A willingness to take the long view of technological accumulation within the firm.

All these challenges and many more must be in the mind of the technology manager before any success in their job can be guaranteed.

\section{A MODEL FOR THE MANAGEMENT OF TECHNOLOGY IN THE DEREGULATED EDI}

The issue of the management of technology is the central focus of this article. The proposed model combines the aspects already discussed: the classification of the technologies (primary and secondary), the industry structures and the reform model (wholesale and retail competition) of the EDI. Figure 2 depicts the reform models and technology classification plane as they can be adopted in an EDI.

An obvious observation is that as the degree of competition (towards full deregulation) increases in any given industry, there is a tendency to move from a centralised to a decentralised decision-making approach. 


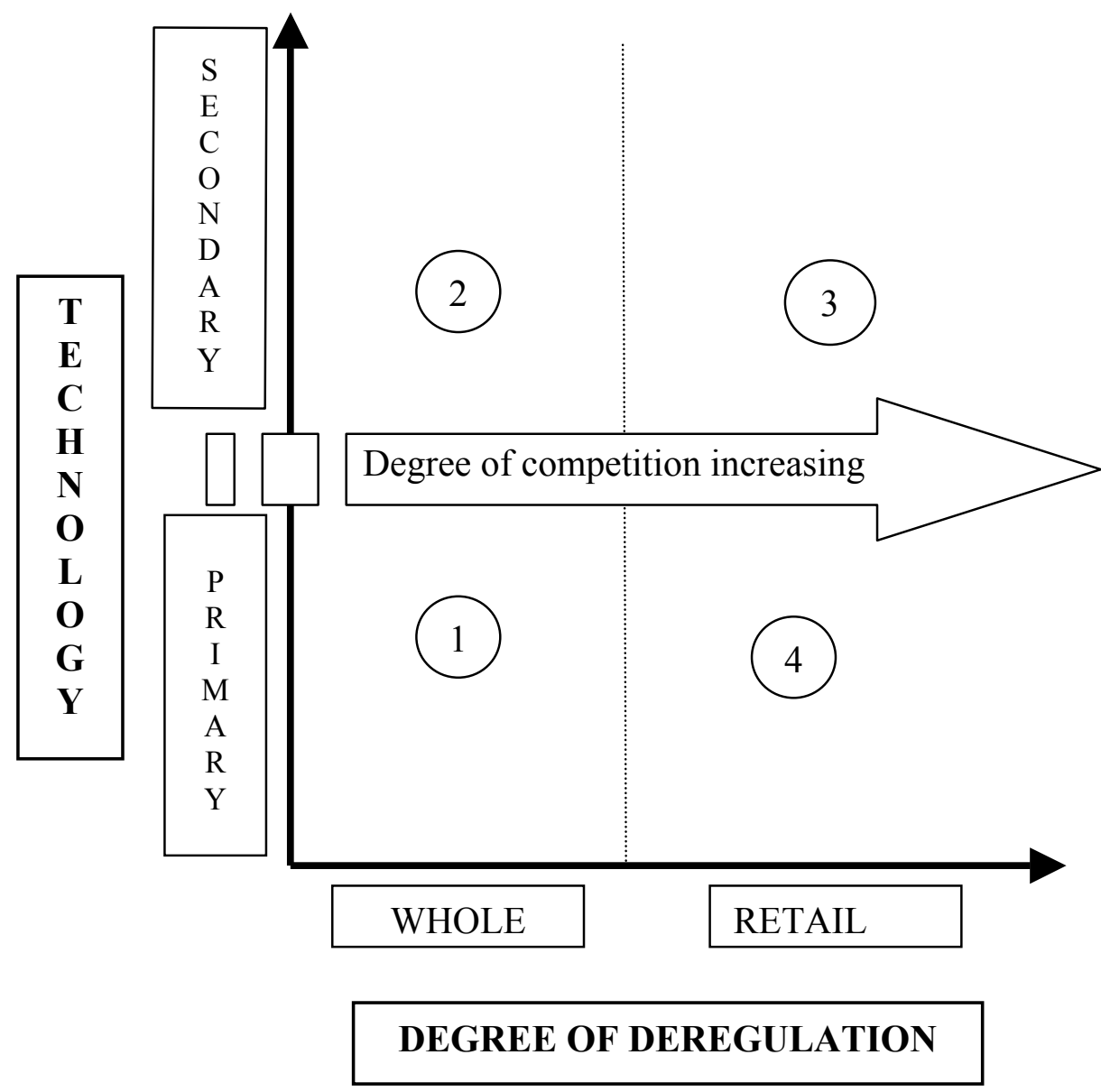

Figure 2: The technology classification - degree of deregulation plane.

In the context of the restructured EDI in South Africa:

a Centralised technology management refers to the situation where the responsibility for the acquisition and exploitation of both primary and secondary plant technologies lies with say an EDI Technology Group.

- Decentralised technology management refers to the scenario where this responsibility lies with the individual regional electricity distributor.

It can therefore be said that the more the electricity distribution industry is opened for competition, the less centralised technology management, for both primary and secondary plant technologies, should be.

As stated earlier, the South African drive for restructuring is made up of two extremes, i.e. a two-sided approach. It strives to bring global competitiveness with an element of social responsibility. This two-sided approach therefore requires a two-sided restructuring approach to the EDI. The following table summarises the model. 


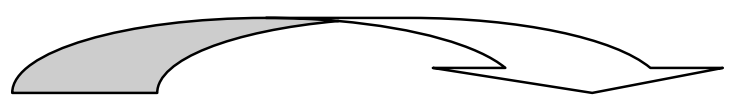

10 years

\begin{tabular}{|c|c|c|c|c|}
\hline Scenario & 1 & 2 & 4 & 3 \\
\hline Model & Wholesale & Competition & Retail & Competition \\
\hline Technology & Primary & Secondary & Primary & Secondary \\
\hline Decision & Centralised & Centralised & Decentralised & Decentralised \\
\hline
\end{tabular}

Table 4: The model for the management of technology in the electricity distribution industry

The model implies: For both scenarios 1 and 2, which are the wholesale competition (modified monopolies) reform model, the acquisition and the exploitation of the secondary and primary plant technologies must be carried out by a centralised group. As suggested earlier, ten years later, when the industry has matured, pure competition can be introduced, and thus the migration to retail competition - real independence.

\section{CONCLUSIONS}

The doubled-sided drive towards the restructuring of the electricity supply industry in South Africa disqualifies the country from adopting a radical approach towards deregulation. In an emerging economy, a phased approach should be adopted. The first phase must address the socio-economic aspect, whilst the second phase can address the business efficiencies, once the playing field has been levelled.

The first phase should incorporate the amalgamation of Eskom's seven distribution regions with the 368 municipal distributors forming the six REDs with the wholesale competition reform model being adopted. The first ten years, phase 1, would be deemed the establishment phase - where the focus will be on social upliftment, e.g. through electrification. During this phase, both secondary and primary plant technologies should be acquired centrally by a group, to be known as the EDI Technology Group/Company. Phase 1 will be an experimentation phase for both the new industry and its customers. Centralised technology management decision making would ensure that the industry benefits from the economies of scale associated with the acquisition of technology, especially primary plant technologies.

Whilst phase 1 will level the playing field, phase 2 will see full-blown competition being introduced. There is no doubt that the second phase will enhance customer service in the industry, especially in technology management aspects as swift service delivery and customised solutions would be easy to provide. 


\section{REFERENCES}

[1] Department of Minerals \& Energy Affairs, The White Paper on Privatisation \& Deregulation in the Republic of South Africa, 1998

[2] Burgelman, R.A, Maidique, M.A, and Wheelwright, S.C., Strategic Management of Technology and Innovation, $2^{\text {nd }}$ edition, Irwin, 1996.

[3] Ford, D. and Saren, M., Technology Strategy for Business, $1^{\text {st }}$ edition, International Thomson Business Press, 1996

[4] De Wet, G., Features of the Technology Colony, article for Technology Management MEM Course 1 1997, University of Pretoria.

[5] Yajima, M., Deregulation of the Electricity Supply Industry - international status of deregulatory reform, Central Research Institute, September 1995.

[6] McGregor, R., Privatisation in South Africa, $1^{\text {st }}$ edition, Juta \& Co, Ltd, 1987.

[7] Maphaka, M., and Mpye, M., "The future energy trading in the South African Electricity Supply Industry, Cigre presentation 2001.

[8] Du Plessis, J., Strategy and Technology: A South African perspective, MEM Research Report, University of Pretoria, 1998 